\title{
Costs of Expanding the Card Catalog of a Large Library
}

Miss Merritt is chief of the Processing Division and $M r$. Frarey is assistant librarian, Duke University Library.

$\mathrm{P}$ ROCEDURES AND TECHNIQUES for expanding the card catalog of a large university library have been described in a previous issue of $C E^{\circ} R L .^{1}$ This account attempts to suggest the costs of an expansion operation which follows in general the procedures discussed by Terry. Like the earlier account, it is based upon the reorganization of a single library catalog, but it may be indicative of the probable scale of the costs of this activity in any library. The figures given here are limited to labor costs alone: expenses for new catalog cabinets are easily determined by application to the various manufacturers of library furniture, and expenses for supplies are negligible if spoiled card stock is used for labels and if there is no need to supply new guide cards throughout the entire catalog.

One reservation should be made at the outset. Local variables will always operate to increase or decrease the costs of any cata$\log$ reorganization. Among the factors bearing upon overall costs are: I. the size of the catalog itself, 2. the manner in which that catalog is organized, 3. prevailing salary scales within the institution, 4 . the extent to which nonprofessional time may be utilized in the operation, and 5. characteristics

1 Terry, Altha E., "Techniques for Expanding the Libraries, I $3: 242 \cdot 45,252$, July, 1 952 .

JANUARY, 1954 of the catalog equipment. (For example, if dual tray label holders are used, trays may be renumbered in less time and at less expense than if single label holders are employed so that tray numbers have to be affixed separately. See below.)

In December, 1952, Duke University Library added a new 624-tray cabinet to its catalog. The Duke Library numbers some $\mathrm{I}, 085,000$ volumes and its catalog is a divided one having three major divisions (exclusive of the Duke copy of the author catalog of the University of North Carolina which is housed in the public catalog room). These divisions are: I. the author-title cata$\log$, 2. the subject catalog, and 3. the serials catalog (a main-entry catalog only). Cards for certain categories of material are excluded from the public catalog. These are: I. author, subject, and title entries for United States documents (an author catalog in the Documents Room supplies this approach, and government indexes furnish a subject guide); 2. author and title entries for United States state publications (a separate author catalog is maintained in the Documents Room); 3. subject entries for materials housed in certain branch or departmental libraries: School of Medicine, Biology-Forestry, Chemistry, Engineering, and Physics-Mathematics; 4. cards for manuscript materials recorded in a separate Manuscripts Catalog; and 5. entries for newspapers which are kept in the Newspaper Room catalog. 
TABLE I

Size of the Duke University Library Catalogs

\begin{tabular}{|c|c|c|c|}
\hline Catalog & $\begin{array}{c}\text { Number } \\
\text { of } \\
\text { Cards }\end{array}$ & $\begin{array}{c}\text { Trays } \\
\text { before } \\
\text { Expan- } \\
\text { sion }\end{array}$ & $\begin{array}{l}\text { Trays } \\
\text { after } \\
\text { Expan- } \\
\text { sion }\end{array}$ \\
\hline $\begin{array}{l}\text { Author-Title } \\
\text { Subject } \\
\text { Serials }\end{array}$ & $\begin{array}{r}977,500 \\
656,550 \\
65,100\end{array}$ & $\begin{array}{r}936 \\
715 \\
60\end{array}$ & $\begin{array}{r}1,430 \\
793 \\
130\end{array}$ \\
\hline Totals & $\mathrm{I}, 699, \mathrm{I} 50$ & $\mathrm{I}, 7 \mathrm{II}$ & 2,353 \\
\hline
\end{tabular}

Table I shows the approximate size of each of the three major divisions of the public catalog enumerated above, together with an indication of the number of catalog trays allocated to each.

The eighteen extra trays shown in this expansion above the 624 new ones result from a reallocation of certain trays in the old catalog from other uses to use for one of these components of the catalog.

In planning for the reorganization certain decisions were made at the outset: I, that the techniques described by Terry would be employed with one significant modification, viz., that the new tray divisions would be determined before any cards were moved, so that permanent tray labels could be available prior to the shift and affixed to the new catalog trays as soon as the shift had been made; 2 . that maximum use would be made of clerical and nonprofessional assistance; and 3. that the move be timed to be completed within the Christmas recess period when most of the students and faculty would be away. At every stage of planning the readers' service units were encouraged to make suggestions which might contribute to an efficient reorganization pro- cedure and an improved catalog.

A brief word may be in order here regarding the routines employed at Duke. Plans for the expansion envisioned a IO-year period before another wholesale reorganization might be required. To this end, calculations allowed for an average of 8 inches of cards per tray in the author-title and serials catalogs, and ro inches per tray in the subject catalog. Space for internal readjustments was provided by leaving top and bottom trays empty. After it was determined how each component of the catalog could be expanded, supervisory professional staff members decided upon the tray divisions for the new catalog and marked them in the old catalog with colored cards. This allowed for maximum use of non-supervisory personnel for the actual shift itself.

In general, the original plans were followed, but a last-minute complication necessitated abandoning the scheme to determine divisions in the subject catalog before shifting any cards so that these divisions were actually worked out as the reorganization itself took place. However, a clerical assistant was assigned to the subject catalog teams so that the permanent labels could be prepared and affixed to the new trays as the work progressed, thus making temporary labels unnecessary.

The cost of the reorganization has been measured at $\$ 425$ for labor costs alone. This figure represents 322 man-hours of work, or, at Duke, the equivalent of one person's time for eight and one-seventh weeks. Table II shows the relative proportion of professional and nonprofessional time involved, and Table III, a breakdown

TABLE II

Catalog Reorganization: Professional and Nonprofessional Costs

\begin{tabular}{|c|c|c|c|c|}
\hline & Hours & Percentage & Cost & Percentage \\
\hline $\begin{array}{l}\text { Professional time } \\
\text { Nonprofessional time }\end{array}$ & $\begin{array}{l}148.5 \\
173.25\end{array}$ & $\begin{array}{l}46 \\
54\end{array}$ & $\begin{array}{r}\$ 262.93 \\
\mathrm{I} 62.80\end{array}$ & $\begin{array}{l}62 \\
38\end{array}$ \\
\hline Totals & 321.75 & $100 \%$ & $\$ 425 \cdot 73$ & $100 \%$ \\
\hline
\end{tabular}


TABLE III

Catalog Reorganization: Expenditures for Activities Involved

\begin{tabular}{|c|c|c|c|c|}
\hline Activity & Hours & $\begin{array}{l}\text { Percentage } \\
\text { of Time }\end{array}$ & Cost & $\begin{array}{c}\text { Percentage } \\
\text { of Cost }\end{array}$ \\
\hline $\begin{array}{l}\text { I. Planning and supervision } \\
\text { 2. Measuring size of catalog } \\
\text { 3. Determining tray divisions } \\
\text { 4. Shifting cards to new trays } \\
\text { 5. Labeling trays } \\
\text { 6. Renumbering trays }\end{array}$ & $\begin{array}{l}18 \\
20 \\
80 \\
90 \cdot 5 \\
44 \cdot 75 \\
68 \cdot 5\end{array}$ & $\begin{array}{r}5.6 \\
6.2 \\
24.9 \\
28.2 \\
13.8 \\
21.3\end{array}$ & $\begin{array}{r}\$ 39.36 \\
21.32 \\
118.98 \\
140.97 \\
44.80 \\
60.30\end{array}$ & $\begin{array}{r}9.2 \\
5.0 \\
28.1 \\
33.1 \\
10.5 \\
14.1 \\
\end{array}$ \\
\hline Totals & 321.75 & $100.0 \%$ & $\$ 425.73$ & $100.0 \%$ \\
\hline
\end{tabular}

of costs by types of activity. Costs were determined by multiplying the amount of time spent by each person engaged in the operation by his determined hourly rate of pay.

It is evident from these figures that if typed labels could have been used to number the trays of the new catalog, costs might have been reduced by 12 to 15 per cent, assuming that the preparation of the number labels would require about as much time as the preparation of the contents labels.

\section{SUMMARY}

In this article an attempt has been made to suggest the nature of costs involved in the reorganization and shifting of a large library catalog through an accounting of the costs of the recent expansion of the Duke University Library Catalog. While variable local factors will affect actual costs of a particular operation, these figures may be helpful to the administrator planning a catalog reorganization in suggesting suitable bases for preparing cost estimates.

\section{Midwest Inter-Library Center}

\section{(Continued from page 49)}

organs, published by commercial and financial firms. Gift.

Current output of theses of all universities in France. 256 received in 1952 . Annual cost, \$306.

Current output of college catalogs issued by American universities. Gift.

Current subscriptions to I I Latin-American medical journals. Received on exchange for subscriptions to its medical journal supplied by a member university.

Current subscriptions to a few miscellaneous periodicals, e.g.:

Economic Reports of the Bank of Taiwan. Gift.

Mathematische-Physicalische Semesterberichte. \$2.50.

Kyoto University Engineering Research Institute Bulletin. Gift.

Prometheus (in modern Greek). \$ro.

Acta Biologica Venezuelica.
NON-SERIAL ITEMS

During its first year and a half, the Center has purchased about ten nonserial or noncontinuing items which member librarians have asked for. Examples are:

Institut (Paris). Sciences Section. 44 volumes. $\$ 226$.

Italy. Two Sicilies. Annali civili del regno delle Due Sicilie. Volumes $\mathrm{I}-42$. \$68.

Three Nineteenth Century German immigrant newspapers on microfilm. Complete files. $\$ 158$.

Opyt Sovetskoi Meditziny (Medical encyclopedia of experiences during the war, I94I-45). 35 volumes. $\$ 350$.

Pravda, March I8, I9I7 through June I938, on microfilm. \$500.

Yank (U.S. Army weekly). New York and overseas editions, I $942-45$, on microfilm. $\$ 250$. 


\section{ACRL Treasurer`s Report and ALA Accommodation Account $1952-53$}

INCOME

ALA Allotments to ACRL from Dues

Budgeted

$\$ 18,000.00$

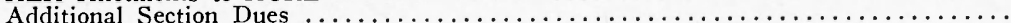

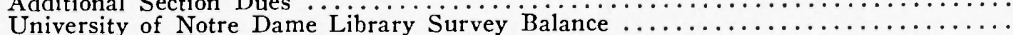

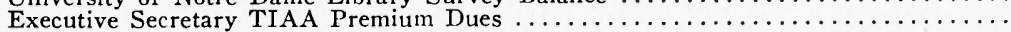

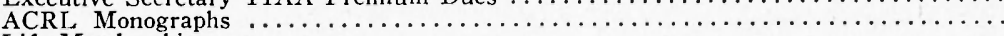

Life Memberships

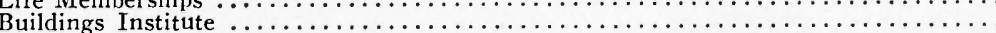

360.00

Miscellaneous Income

=

Actual

$\$ 21,949.77^{*}$

I 33.90
378.49
376.00

360.00

$3, \mathrm{r} 98.06$

$\mathrm{I} 2.00$
200.00

Total Income

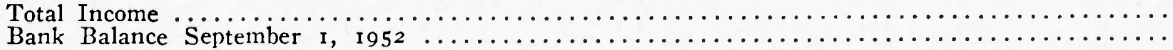

Total

\section{EXPENDITURES}

C\&RL Subvention

Annual Conference Expense

$3,750.00$

250.00

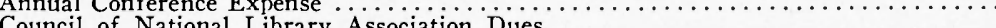

Council of National Library Association Dues

American Council on Education (Membership)

American Council on Education (Membership)
Joint Committee on Library Work as a Career

I 0.00

5.00

25.00

50.00

200.00
787.50

$\$ 2,935.25$

100.00

10.00

5.00

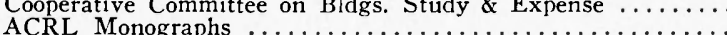

$\overline{2,099.84}$

\section{SECTION EXPENSES}

College

I 00.00

I 50.00

I 00.00

75.00

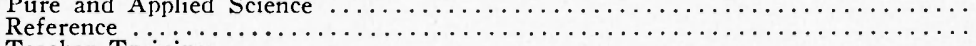

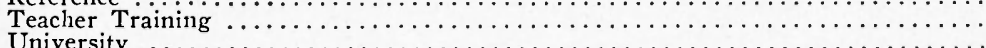

75.00

$\$ 49.08$

I 65.45

I 12.26

96.84

35.00

COMMITTEF EXPENSES

Administrative Procedures

$\$ 25.00$

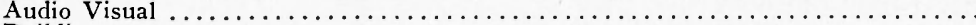

Buildings

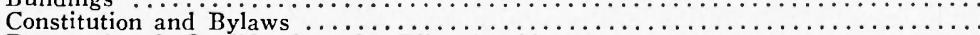

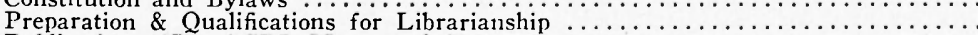

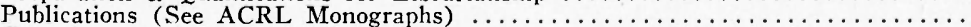

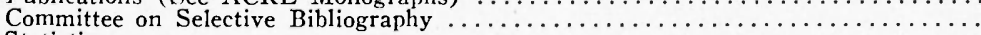

Statistics

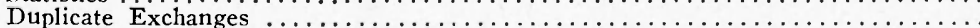

OFFICERS' EXPENSE

President

Treasurer

Fxera Administrative Expense (Including Travel)

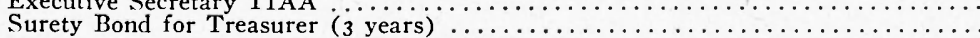

EXECUTIVE OFFICE EXPENSE

Salaries (2T/2) Social Security, Insurance

Travel Expenses of Executive Secretary

Addressograph Plates

Communications, Supplies, etc.

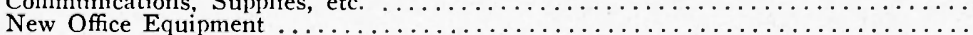

Total Expenditures

50.00

437.50

$\$ 25.00$

50.00

850.00

720.00

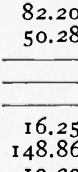

I 9.29

$\$$

50.00
821.55
730.00
81.25

$\$ 12,350.00$
$1,300.00$
125.00
500.00
100.00

$\$ 12,62$ I . 83

I, I I 5.23

I 02.74

917.80

$\$ 22,391.00$

\$ I 2,957.75

26,233. I 2

$\$ 39,190.87$

$-22,391.00$

$\$$ I $6,799.87$ *

Balance

* Of this total $\$ 1.006 .55$ was naid to AC.RI, by AI,A in late Sentember, I052, in order to balance out the account for I05I-52. \$r.006.55 is therefore properly part of the I95I-52 dues, and the actual allotments for I952-53 should be reduced by this amoint.

* \$ 5,000.00 in Savings Arcount at Safety Federal Savings \& Loan. Kansas City, Missouri.

$\$ \mathrm{I}, 799.87$ in Checking Account at First National Bank, Kansas City, Missouri. 